東京都区部の応急仮設住宅からみた公園の必要量に関する考察

A STUDY ON THE NEEDED AREA OF PARKS WITHIN THE (23) WARDS OF TOKYO THROUGH TEMPORARY HOUSINGS CONSTRUCTION

\author{
三船康 道*, 蔉田 Uろ子** \\ Yasumichi MIFUNE and Hiroko MINODA
}

\begin{abstract}
It is ideal that cities can deal with the emergent land utilization with public open spaces.

This study is about the parks of public open spaces from the view-point of temporary housings construction. It contains the arrangement of temporary housings in parks, the simulation of the number of refugees accomodated in the housings and the comparison with needed temporary housings based on the estimation of damage. It also refers to the comparison between the target area of long term plan for the Tokyo metropolis and the standard area of city parks act for parks area for needed temporary housings.
\end{abstract}

Keywords : The(23)wards of Tokyo, Earthquake, Natural disaster, Park, Temporary housing 東京都区部、地震、自然災害、公園、応急仮設住宅

1.はじめに

阪神・淡路大震災で、応急仮設住宅は公有地以外に民有地にも建 設され、また学校が避難所となったため仮設校舎を建設した学校も あり、応急仮設住宅の建設は新たな検討の必要性を提起した。

都市は、災害にあっても他の機能に支障を与えず回復できること が望まれる。また遠隔地に建設された応急仮設住宅の場合、空室が 多いという状況もあるように、応急仮設住宅の建設場所は基本的に 居住地の近くが求められよう。そのために、理想的な都市は、災害 時に近くの公共のオープンスペースで、応急仮設住宅の建設が可能 となるような、余裕を持つべきであろう。

オープンスペースの利用については、避難場所としての利用は各 自治体で決められてるが、応急仮設住宅の建設用地については未だ 不十分である。阪神・淡路大震災の反省を踏まえ、オープンスペー スの評価として応急仮設住宅の収容力も検討されるべきであろう。 以上のような観点から本研究では、東京都23区が被災した場合を 想定して、現在の公園・緑地を利用した場合の応急仮設住宅の収容 能力を検討し、そしてその場合の被害想定との比較検討を行う ${ }^{11}$ 。 さらに、東京都の長期計画における目標值及び現行の都市公園法に おける公園の設置基準との比較考察を行う。
2.ケーススタディの方法 まず東京都23区を対象に、公共のオープンスペースの中から、公 園・緑地を応急仮設住宅（以後仮設住宅という）建設用地とし、阪 神・淡路大震災で使用されている仮設住宅を各公園・緑地に配置し、 各区ごとに仮設住宅の収容能力を集計する。

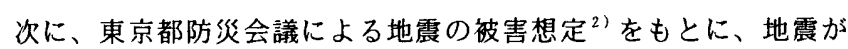
発生した際に必要とされる仮設住宅数を算出する。そして、公園の 収容能力と被害想定による必要仮設住宅数により、不足仮設住宅数 を算出し、それを収容するための不足用地面積を算出する。

仮設住宅対策は、近くのオープンスペースということを前提にす ると、原則として区単位での対応が考えられる。しかし、場合によ ってはブロック単位での対応も考えられる(ここでブロックとは東 京都長期計画" ック単位を超えて区部全域での対応も考えられる。そのため、ここ で集計は、区単位、ブロック単位、及び区部全域の 3 段階で集計し、 それそれの段階で、不足用地面積に対する検討を行う。

そして、最後に仮設住宅を収容するための必要公園面積と、東京 都の長期計画による目標值と、都市公園法における公園の設置標準 と比較考察を行う。
* 秼エコプラン 工博

** (侏エコプラン 


\section{3. 現在の公園における収容可能数}

ここでは、最初に仮設住宅の平面を設定する。次に、仮設住宅の 建設用地としての公園の条件を定め、対象公園を設定し、仮設住宅 配置の条件を定め地図上で配置し、これを樹木を除去した場合の収 容可能数とする。そしてこの収容可能数に、樹木があった場合の調 整を行い、樹木を除去しない場合の収容可能数を算出し、戸当たり 公園面積を求める。

\section{（1）仮設住宅の平面}

阪神・淡路大震災では、仮設住宅は 2 タイプ使用されているが、 ここでは、そのうちの間口 $3.6 \mathrm{~m} 、$ 奥行 $7.2 \mathrm{~m}$ 、面積 $25.92 \mathrm{~m}^{2}$ の $2 \mathrm{D} \mathrm{K}$ タイプとした（図１）。
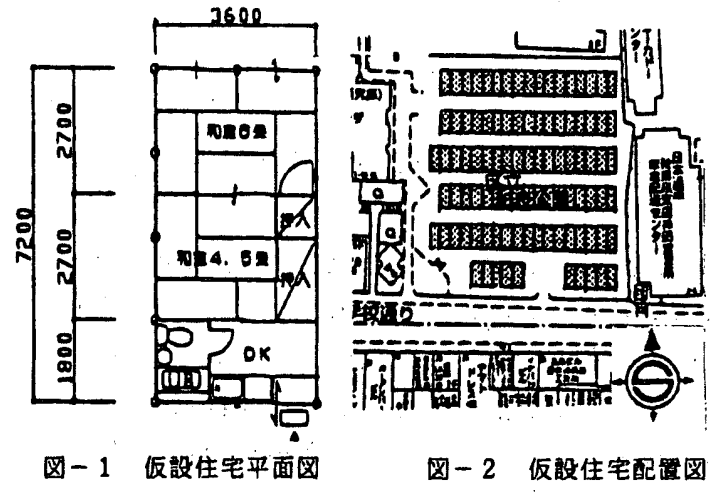

表. 1 对象公圈データ

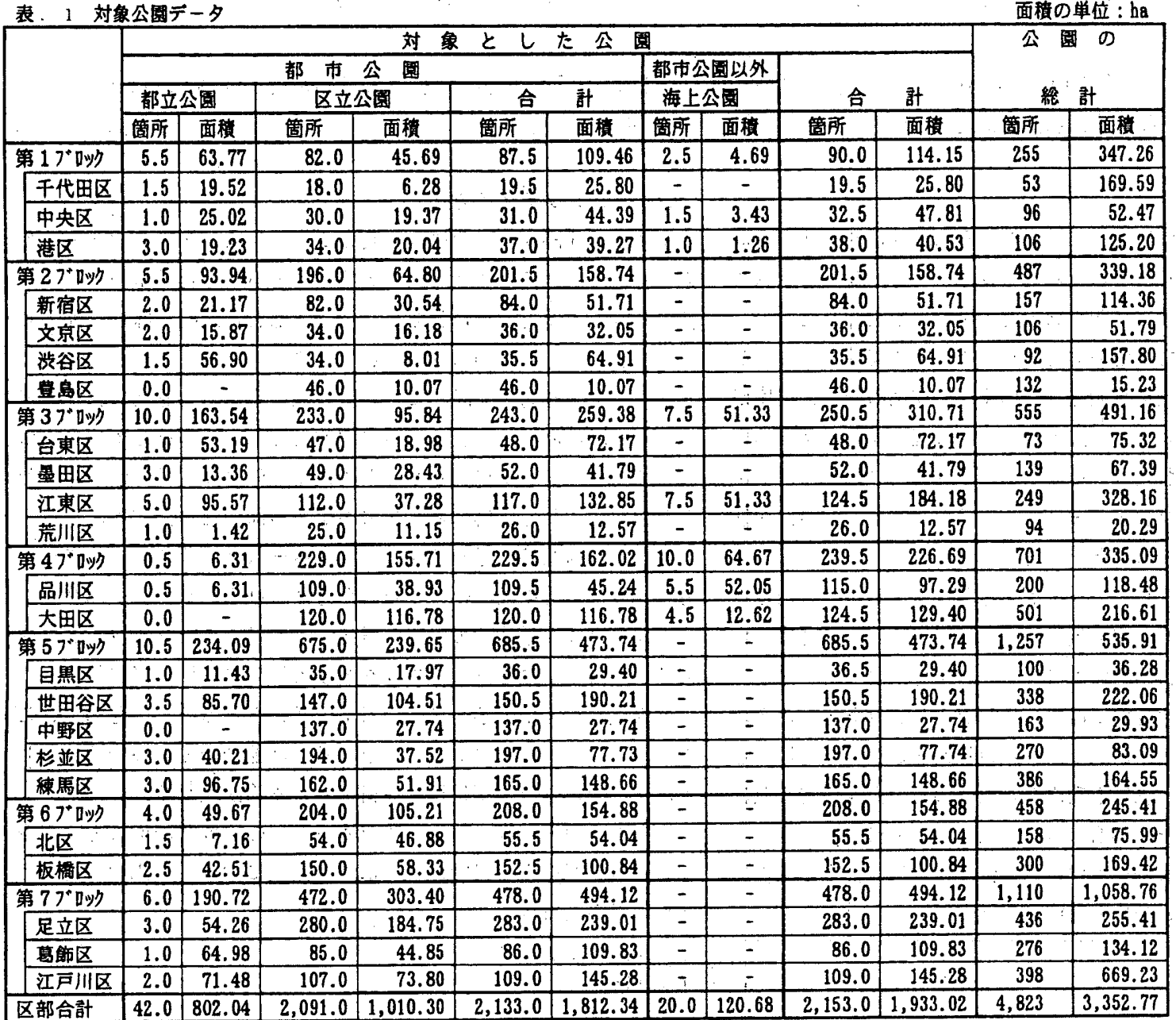

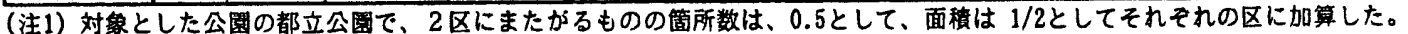

（注2）公園の総数のテータは公園調曺による。

\section{（2）対象公共オープンスペース}

建設用地には、公共のオープンスペースの中で、都市公園からは 都立公園、区立公園、そして都市公園以外の公園として海上公園を 対象とした" ${ }^{4 !}$ 。海上公園でも、橋のみでつながっている人工島のも のは橋の被害により孤立化のおそれがあり、また、工場用地として 利用されている人工島のものは人が住んでいないため除いた。

また、都市公園以外のオープンスペースとして、児童遊園もある が、児童遊園は規模も小さく、また地域の物資の配送挟点や、ボラ ンティア等の応援活動の拋点等の用途も考えられ、ここでは除いた。 さらに皇居外苑等の国民公園も除き、区部全域で 2,153箇所の公 園を対象とした。公園面積の合計は1,933.02haであった（表．1）。 (3) 配置の方法

仮設住宅の配置には、住宅地図 $(1 / 2,000)^{5)}$ を使用し、地図上 で各公園每に以下のような方針で配置した（図２）。

(1)净水場等の施設の屋上利用の公園、及び公園部分は対象外とする。 (2)河川教を利用している公園・緑地については、川沿いで堤防の内 側のものは対象外とする。

(3)地図上に池、植え込み、湿地、水田、烟、花壇、噴水、通路、便 所等の施設及び、その他の構造物がある場合には、それらをよけ て配置する。

(4)敷地の起伏にあっては、階段、擁壁、のり面等地図上の記載を考 慮し配置する。

(5)敷地境界、及び (3)(4)の施設や構 構造物等からは $2 \mathrm{~m}$ 以上離す。 6住戸は原則とし 南向きの平行配 置とし、敷地の 形状等の条件で 難しい場合は東 南向きの配置と し、隣楝間㢼は $4 \mathrm{~m}$ とする。

(4) 収容可能数

（3）の方法は、 一階建てで樹林を 除去した場合に当 たる。集計結果、 収容可能数は区部 合計で 201，738户 であった（表。

2)

次に、樹木を除 去しない場合り収 容可能数を算出寸 るため、ここでは、 
樹木を除去した場合の収容可能数に、公園・緑地の樹木に被覆され ない面積率（100-公園・緑地の樹木被稪率 $\left.(\%)^{6)}\right)$ を乗じ、これ を樹木非除去の収容可能数とした。ここで、公園・緑地の樹木被覆 率は、現時点での各区の最新デー夕を使うこととした。

\begin{tabular}{|c|c|c|c|c|}
\hline $\begin{array}{c}\text { 樹木非除去 } \\
\text { 収容数 }\end{array}$ & & $\begin{array}{l}\text { 樹木除去 } \\
\text { 収容数 } \\
\end{array}$ & $x$ & $\frac{100-\text { 公園緑地樹木被覆率 }}{100}$ \\
\hline
\end{tabular}

計算結果、一階建てによる現在の公園における樹木非除去の場合 の収容可能数は、区部合計で 137,075戸であった。

\section{（5）戸当たり公園面皘}

一階建ての一戸当たりの公園面積として、仮設住宅建設を対象と した公園面積の合計を、樹木非除去の場合の収容可能数で除した。

この場合、区単位では戸当たり公園面積は区によって大きく異な

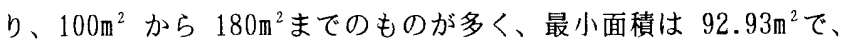
最大面積は $544.37 \mathrm{~m}^{2}$ であった。ブロック単位では最小面積は 112.19 $\mathrm{m}^{2}$ で、最大面積は $266.96 \mathrm{~m}^{2}$ であった。また、区部全体での戸当たり 公園面樍の平均値は、141.02年であった（表，2）。

\section{4.被䓊想定による必要仮設住宅数}

\section{（1）東京都の被害想定}

東京都防災会議による地震の被害想定 ${ }^{2)}$ には、住宅の焼失と倒壊、 及びライフラインの供給停止による住居制約世帯数が推計されてい る。仮設住宅の戸数を算出するための数値として、ライフラインの 被害はいずれ復旧するため除き、ここでは焼失と倒壊による住居制 約世帯の数值を用いた。

また、地震発生から 1 日後、2 3 日後、一週間後の、経過日数

\begin{tabular}{|c|c|c|c|c|}
\hline & $\begin{array}{l}\text { 樹木除去 } \\
\text { 収容数(六) } \\
\end{array}$ & $\begin{array}{c}\text { 樹木被覆率 } \\
(\%) \\
(\%)\end{array}$ & $\begin{array}{l}\text { 樹木非除去 } \\
\text { 収容数 (局) }\end{array}$ & $\begin{array}{l}\bar{P} \text { 当たり面 } \\
\text { 皘 }\left(\mathrm{m}^{2} / \bar{p}\right)\end{array}$ \\
\hline 第 1プロック & 8,924 & - & 5,977 & 190.96 \\
\hline 千代田区 & 1,360 & 65.1 & 474 & 544.37 \\
\hline 中央区 & 4,035 & 32.7 & 2,715 & 176.11 \\
\hline 港区 & 3,529 & 20.98 & 2,788 & 145.34 \\
\hline 第 2 ブロック & 17,698 & - & 5,946 & 266.96 \\
\hline 新宿区 & 4,741 & 52.7 & 2,242 & 230.66 \\
\hline 文京区 & 2,628 & 69.1 & 812 & 394.65 \\
\hline 沾谷区 & 9,175 & 76.2 & 2,183 & 297.33 \\
\hline$\sqrt{\text { 豊島区 }}$ & 1,154 & 38.5 & 709 & 142.00 \\
\hline 第 3プロック & 24,675 & - & 18,890 & 164.48 \\
\hline 台東区 & 3,827 & 18.86 & 3,105 & 232.44 \\
\hline 墨田区 & 3,355 & 15.2 & 2,845 & 146.88 \\
\hline 江東区 & 16,063 & 26.7 & 11,774 & 156.43 \\
\hline 荒川区 & 1,430 & 18.4 & 1,166 & 107.80 \\
\hline 第 4プロック & 24,911 & - & 17,079 & 132.73 \\
\hline \begin{tabular}{|l} 
品川区 \\
\end{tabular} & 10,344 & 40.2 & 6,185 & 157.30 \\
\hline 大田区 & 14,567 & 25.21 & 10,894 & 118.78 \\
\hline 第 5 ブロック & 55,950 & - & 35,253 & 134.39 \\
\hline 目黑区 & 3,097 & 59.3 & 1,260 & 233.34 \\
\hline 世田谷区 & 20,403 & 42.1 & 11,813 & 161.02 \\
\hline 中野区 & 3,165 & 16.4 & 2,645 & 104.87 \\
\hline 杉並区 & 7,589 & 18.97 & 6,149 & 126.42 \\
\hline 練馬区 & 21,696 & 38.3 & 13,386 & 111.06 \\
\hline 第6プロック & 13,002 & - & 9,888 & 156.64 \\
\hline 北区 & 4,304 & 10.2 & 3,864 & 139.86 \\
\hline 板橋区 & 8,698 & 30.74 & 6,024 & 167.39 \\
\hline 第7プロック & 56,578 & - & 44,042 & 112.19 \\
\hline 足立区 & 24,762 & 25.0 & 18,571 & 128.70 \\
\hline 葛飾区 & 15,676 & 24.6 & 11,819 & 92.93 \\
\hline 江戸川区 & 16,140 & 15.41 & 13,652 & 106.42 \\
\hline 区部合計 & 201,738 & - & 137,075 & 141.02 \\
\hline
\end{tabular}

（注1）仮設住宅数は住宅地図に配置した住宅数。

（注 2 ）江声川区、杉並区については、区全体の緑被率を用いた。

ごとの推計值があるが、被害の最大値を示している 2 ～ 3 日後と一 週間後の推計值を用いた。その結果、仮設住宅を算出するための住 居制約世帯数は、区部合計で 782,803世帯であった（表３）。

\section{（2）仮設住宅の必要戸数}

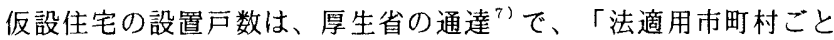
に全焼、全壊及び流出世帯数の合計の3 割以内」と規定されている。 近年の災害では 3 割を上回る戸数が建設された例もあり、設置戸 数の検討も課題である。しかし、3 割を超えたものは阪神・淡路大 震災に比べ被災戸数が少なく、阪神・淡路大震災では被災戸数が多 く用地不足ということもあり、3 割以下という限度内で抑えられて いる(1)。今回のスタディでは大規模災害を想定しているため、厚 生省の通達の最大值により必要戸数を想定する。

住居制約世帯数の3 割として算出した結果、区部の必要仮設住宅 数の合計は、234,850戸となった（表．3）。

\section{5. 不足仮設住宅数と不足用地面積}

公園・緑地での仮設住宅の収容可能数と被害想定による必要仮設 住宅数に不足がでた場合、不足分をカバーするため、民間等のオ一 プンスペースが必要となる。ここでは今までの計算結果に基づき、 不足仮設住宅数と不足用地面積について検討、考察を行う。検討、 考察は、公園・緑地における仮設住宅の最大限の収容力を考慮し、 それそれ樹木除去の場合と樹木非除去の場合、及び仮設住宅が一階 建ての場合と二階建ての場合について行う。ここで不足用地面積は、 仮設住宅一戸当たり $50 \mathrm{~m}^{2}$ を最小必要面積として算出する ${ }^{8)}$ 。

ここで、区単位での集計は、収容可能数の余裕と不足仮設住宅数 を区相互間で調整せず区単位で処理することとし、集計は収容可能

\begin{tabular}{|c|c|c|}
\hline & $\begin{array}{l}\text { 住宅制約世 } \\
\text { 帯数(世帯) }\end{array}$ & $\begin{array}{l}\text { 必要仮設住 } \\
\text { 宅数(戸) }\end{array}$ \\
\hline 第1プロック & 9,848 & 2,955 \\
\hline 千代田区 & 1,610 & 483 \\
\hline 中央区 & 2,397 & 720 \\
\hline 港区 & 5,841 & 1,753 \\
\hline 第 2フロック & 101,338 & 30,403 \\
\hline \begin{tabular}{|l} 
新宿区 \\
\end{tabular} & 21,525 & 6,458 \\
\hline 文京区 & 19,931 & 5,980 \\
\hline 橴谷区 & 21,202 & 6,361 \\
\hline \begin{tabular}{|l|} 
豊島区 \\
\end{tabular} & 38,680 & 11,604 \\
\hline 第 3フロック & 59,647 & 17,896 \\
\hline 台東区 & 13,313 & 3,994 \\
\hline 墨田区 & 21,329 & 6,399 \\
\hline 江東区 & 13,091 & 3,928 \\
\hline 荒川区 & 11,914 & 3,575 \\
\hline 第 4フロック & 132,008 & 39,604 \\
\hline 品川区 & 52,501 & 15,751 \\
\hline 大田区 & 79,507 & 23,853 \\
\hline 第 5 ブロック & 275,353 & 82,607 \\
\hline 目黑区 & 28,069 & 8,421 \\
\hline 世田谷区 & 105,772 & 31,732 \\
\hline 中野区 & 49,010 & 14,703 \\
\hline 杉並区 & 63,170 & 18,951 \\
\hline $\begin{array}{l}\text { 練馬区 } \\
\end{array}$ & 29,332 & 8,800 \\
\hline 第 6プロック & 59,149 & 17,745 \\
\hline 北区 & 24,186 & 7,256 \\
\hline 板橋区 & 34,963 & 10,489 \\
\hline 第 7プロック & 145,460 & 43,639 \\
\hline 足立区 & 50,943 & 15,283 \\
\hline 葛飾区 & 49,409 & 14,823 \\
\hline 江戸川区 & 45,108 & 13,533 \\
\hline 部合計 & 782,803 & 234,850 \\
\hline
\end{tabular}

（注）ここでの住居制約世帯とは、焼失 倒壊による住居制約世帯をいう。
数に余裕のある区を除 き、不足が生じた区の 值を合計した。

ブロック単位での集 計は、各区で発生した 収容可能数の余裕と不 足仮設住宅数をブロッ ク内で調整することと し、集計は収容可能数 に余裕のあるブロック を除き、不足が生じた ブロックの值を合計し た。

区部全域での集計は、 各区で発生した収容可 能数の余裕と不足仮設 住宅数を、区部全域で 調整することとし、集 計は区の余裕数と不足 数を23区全体で集計し た（表４）。 


\section{（1）樹木除去の場合}

仮設住宅が一階建ての場合は、区単位、ブック単位とも余裕の ある場合もあったが、合計では区部全域も含めて不足であった。し かし、二階建ての場合、区単位では 6 区が不足し、フロック単位で は全てのブロックの不足が解消され、合計では、ブロック単位と区 部全域で不足が解消された（表. 4)。

\section{（2）樹木非除去の場合}

仮設住宅が一階建ての場合は 6 区で余裕があり、合計では区単位、 ブロック単位、区部全域とも全て不足した。しかし、二階建ての場 合は、11区の不足が解消され、合計では区部全域の場合に不足が解 消された（表４）。

\section{（３）まとめ}

樹木を除去した場合、一階建てでは 9 区の不足が解消され、また、 二階建てでは、不足する区は 6 区あるが、ブロック単位でも不足が 解消され、概わ不足が解消されることがわかった。また、樹木を除 去しない場合にあっては、二階建てで11区の不足が解消され、区部 全域で対応する場合に合計の不足が解消されることがわかった。

\section{6 ，不足公園面積と必要公園面栍の考察}

ここでは、仮設住宅建設のための不足公園面櫴の結果と、被害想 定による必要仮設住宅数収用のための必要公園面積と東京都の長期 計画の目標值による公園面樌、及び都市公園法の設置基準による都 市公園の面積との比較考察を行う。
ここで不足公園面積と必要公園面積を算出する際の原単位を、樹 木を除去しないで、仮設住宅が一階建ての場合の必要な公園面䄼と し、ここでは戸当たり必要公園面樍として $150 \mathrm{~m}^{2}$ とする ${ }^{9)}$ 。

従って、不足公園面櫴は、表. 4 の樹木非除去の一階建ての場合 の不足戸数に $150 \mathrm{~m}^{2}$ を乗じた値とする。

また、必要公園面糟は現状の公園を踏まえ、新設の公園を仮設住 宅の建設対象となる公園とし、表. 1 の公園の総計の面樌に、不足 公園面積を加えたものとする。

$$
\begin{aligned}
& \text { 不足公園面樌 }=\text { 不足仮設住宅戸数 } \times 150 \mathrm{~m}^{2} \\
& \text { 必要公園面積 }=\text { 公園面積の総計 }+ \text { 不足公園面䅐 }
\end{aligned}
$$

都市公園については、都市公園法に基づき、一つの市町村の住民 1 人当たり $10 \mathrm{~m}^{2}$ 以上、市街地においては市街地住民 1 人当たり $5 \mathrm{~m}^{2}$ 以上と規定されている ${ }^{10)}$ 。しかし、東京都では都の長期計画で独自 に目標値を 1 人当たり $6 \mathrm{~m}^{2}$ と定めている ${ }^{11}$

従って、仮設住宅のための必要公園面積を、東京都の長期計画の 目標値の 1 人当たり $6 \mathrm{~m}^{2}$ で確保した場合、及び都市公園法の標準値 の 1 人当たり $10 \mathrm{~m}^{2} て ゙$ 確保した場合と比較する ${ }^{12)}$ 。

\section{（1）不足公園面積}

不足する区は17区で、区単位での合計は1,749.66ha不足し、区部 全域では、区単位より約 $300 \mathrm{ha}$ 少なくなった（表，5）。

（２）必要公園面䅪

1 ) 東京都長期計画の目標値との比較

\begin{tabular}{|c|c|c|c|c|c|c|c|c|c|}
\hline \multirow{3}{*}{\multicolumn{2}{|c|}{. }} & \multicolumn{4}{|c|}{ 樹 木 除 去 $の$ 場 合 } & \multicolumn{4}{|c|}{ 榯 木 非 除 去 $の$ 場 合 } \\
\hline & & \multicolumn{2}{|c|}{ 1跸建ての場合 } & \multicolumn{2}{|c|}{2 階建ての場合 } & \multicolumn{2}{|c|}{ 1階建ての場合 } & \multicolumn{2}{|c|}{2 谐建ての場合 } \\
\hline & & 不距 & 不足面借(ha) & 不跃数 $(\bar{F})$ & 不足鯂(ha) & 不足所 & 不足面聶(ha) & 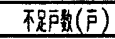 & 不足酶（ha) \\
\hline & 1 プロック & $(5,968)$ & 0.00 & $(14,892)$ & 0.00 & $(3,021)$ & 0.00 & $(8,998)$ & 0.00 \\
\hline & f代田区 & $(877)$ & 0.00 & $(2,237)$ & 0.00 & 9 & 0.05 & $(465)$ & 0.00 \\
\hline & 中央区 & $(3,315)$ & 0.00 & $(7,350)$ & 0.00 & $(1,995)$ & 0.00 & $(4,710)$ & 0.00 \\
\hline & 巷区 & $(1,776)$ & 0.00 & $(5,305)$ & 0.00 & $(1,035)$ & 0.00 & $(3,823)$ & 0.00 \\
\hline & 2プロック & 12,705 & 63.53 & $(4,993)$ & 0.00 & 24,475 & 122.29 & 18,511 & 92.56 \\
\hline & 所宿区 & 1,717 & 8.59 & $(3,024)$ & 0.00 & 4,216 & 21.08 & 1,974 & 9.87 \\
\hline & 交京区 & 3,352 & 16.76 & 724 & 3.62 & 5,168 & 25.84 & 4.356 & 21.78 \\
\hline & 点谷区 & $(2,814)$ & 0.00 & $(11,989)$ & 0.00 & 4,178 & 20.89 & 1,995 & 9.98 \\
\hline & 貹畕区 & 10,450 & 52.25 & 9,296 & 46.48 & 10,895 & 54.48 & 10,186 & 50.93 \\
\hline & 3フロック & $(6,779)$ & 0.00 & $(31,454)$ & 0.00 & $(994)$ & 0.00 & $(19,884)$ & 0.00 \\
\hline & 台東区 & 167 & 0.84 & $(3,660)$ & 0.00 & 889 & 4.45 & $(2,216)$ & 0.00 \\
\hline & 熏田区 & 3,044 & 15.22 & (311) & 0.00 & 3,554 & 17.77 & 709 & 3.55 \\
\hline & I東区 & $(12,135)$ & 0.00 & $(28,198)$ & 0.00 & $(7,846)$ & 0.00 & $(19,620)$ & 0.00 \\
\hline & 兌川区 & 2,145 & 10.73 & 715 & 3.58 & 2,409 & 12.05 & 1,243 & 6.22 \\
\hline & 4プロック & 14,693 & 73.47 & $(10,218)$ & 0.00 & 22,525 & 111.63 & 5,446 & 27.23 \\
\hline & 名川区 & 5,407 & 27.04 & $(4,937)$ & 0.00 & 9,566 & 47.83 & 3,381 & 16.91 \\
\hline & 大田区 & 9,286 & 46.43 & $(5,281)$ & 0.00 & 12,959 & 64.80 & 2,065 & 10.33 \\
\hline & 5フロック & 26,657 & 133.29 & $(29,293)$ & 0.00 & 47,354 & 236.77 & 12,101 & 60.51 \\
\hline & 当黒区 & 5,324 & 26.62 & 2,227 & 11.14 & 7,161 & 35.81 & 5,901 & 29.51 \\
\hline & 世田谷区 & 11,329 & 56.65 & $(9,074)$ & 0.00 & 19,919 & 99.60 & 8,106 & 40.53 \\
\hline & 中野区 & 11,538 & 57.69 & 8,373 & 41.87 & 12,058 & 60.29 & 9,413 & 47.07 \\
\hline & 軓区 & 11,362 & 56.81 & 3,773 & 18.87 & 12,802 & 64.01 & 6,653 & 33.27 \\
\hline & 東馬区 & $(12,896)$ & 0.00 & $(34,592)$ & 0.00 & $(4,586)$ & 0.00 & $(17,972)$ & 0.00 \\
\hline & $6 フ ォ ロ ッ ク$ & 4,743 & 23.72 & $(8,259)$ & 0.00 & 7,857 & 39.29 & $(2,031)$ & 0.00 \\
\hline & t区 & 2,952 & 14.76 & $(1,352)$ & 0.00 & 3,392 & 16.96 & $(472)$ & 0.00 \\
\hline & 反檽区 & 1,791 & 8.96 & $(6,907)$ & 0.00 & 4,465 & 22.33 & $(1,559)$ & 0.00 \\
\hline & 7 フロック & $(12,939)$ & 0.00 & $(69,517)$ & 0.00 & $(403)$ & 0.00 & $(44,445)$ & 0.00 \\
\hline & 立区 & $(9,479)$ & 0.00 & $(34,241)$ & 0.00 & $(3,288)$ & 0.00 & $(21,859)$ & 0.00 \\
\hline & 尞飾区 & $(853)$ & 0.00 & $(16,529)$ & 0.00 & 3,004 & 15.02 & $(8,815)$ & 0.00 \\
\hline & I所川区 & $(2,607)$ & 0.00 & $(18,747)$ & 0.00 & (119) & 0.00 & $(13,771)$ & 0.00 \\
\hline 合 & 区単位 & 79,864 & 399.32 & 25,108 & 125.54 & 116,644 & 583.22 & 55,982 & 279.91 \\
\hline & プロック & 58,798 & 293.99 & $(168,626)$ & 0.00 & 102,193 & 510.97 & 36,058 & 180.29 \\
\hline 計 & 区部全域 & 33,112 & 165.56 & $(168,626)$ & 0.00 & 97,775 & 488.88 & $(39,300)$ & 0.00 \\
\hline
\end{tabular}
榯木非除去 の場 合

（注1）不足戸数の（）内の数值は余裕戸数。

（注 2 ）不足面積の合計は、区単位、フロック単位、区部全域の不足戸数の合計に $50 \mathrm{~m}^{2} を$ 乗じた。
仮設住宅建設に余裕 のある区で、公園面樌 が目標値より少ないの は 2 区で、6区中 4 区 が目標值より多くの公 園を確保している。

公園が不足する区の うち、目標值で公園を 確保しても必要公園面 積が不足する区は、17 区中 9 区 $(52.9 \%)$ あ うた。

合計を見ると、目標 值では区単位、ブロッ ク笚位、区部全域でも 必要公園面積には満た ない。しかし、区部全 域の場合、目標値で足 りないのは 12.44 haで、

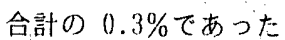
(表.5)。 


\section{2 ）都市公園の標準值との比較}

都市公園の標準值で公園を確保した場合と比較すると、区単位で は、千代田区と渋谷区が必要公園面積に満たない結果となった。ブ ロック単位では、第 1 ブロックの場合、都市公園の標準値による公 園面積が仮設住宅設置必要公園面積より少ないが、これは千代田区 の事情による。それ以外の区及びブロック、また、区部全域では仮 設住宅の建設用地は確保される結果となった（表．5）。

千代田区と渋谷区では、既存の仮設住宅設置を対象としない公園 が多く、そのため仮設住宅設置必要公園面積の值が大きくなり、例 外的である。従って、概攻都市公園の標準值では必要公園面積を満 たすことが可能である。

\section{7.まとめ}

東京都23区で仮設住宅の建設用地として、公園・緑地を対象に検 討した結果、被害想定による必要仮設住宅数に対して、現状で建設 可能な仮設住宅数は多量に不足していることがわかった。

樹木を除去せず仮設住宅を一階建てとして、東京都の長期計画の 目標値、1人当たり $6 \mathrm{~m}^{2}$ で公園を確保する場合と比較した結果、必 要仮設住宅数を収容することは出来なかった。

しかし、都市公園法の標準值、1 人当たり $10 \mathrm{~m}^{2}$ で公園を確保する 場合と比較した結果、区単位でみた場合不足する区が 2 区あったが、 概水収容すると思われる結果が得られた。

また、現状の公園・緑地での不足仮設住宅分を、公園・緑地以外

\begin{tabular}{|c|c|c|c|c|}
\hline 不足 & 園面積と必 & 公園面積の & & 単位：ha \\
\hline & $\begin{array}{c}\text { 不足公園 } \\
\text { 面積 }\end{array}$ & $\begin{array}{c}\text { 仮設住宅設 } \\
\text { 置必要公園 } \\
\text { 面䅅 }\end{array}$ & $\begin{array}{l}\text { 都長期計画 } \\
\text { の目標面皘 } \\
\left(6 \mathrm{~m}^{2} / 人\right) \\
\end{array}$ & $\begin{array}{l}\text { 都市公園法 } \\
\text { の標準面積 } \\
\left(10 \mathrm{~m}^{2} / \lambda\right) \\
\end{array}$ \\
\hline 第1プロック & 0.00 & * 347.26 & 147.00 & 245.00 \\
\hline 千代田区 & 0.14 & 169.73 & 20.34 & 33.90 \\
\hline 中央区 & 0.00 & * $\quad 52.47$ & 38.94 & 64.90 \\
\hline 港区 & 0.00 & * 125.20 & 87.72 & 146.20 \\
\hline 第 2 フロック & 367.13 & 766.31 & 532.56 & 887.60 \\
\hline 新宿区 & 63.24 & 177.60 & 165.36 & 275.60 \\
\hline 文京区 & 77.52 & 129.31 & 103.44 & 172.40 \\
\hline 渋谷区 & 62.67 & 220.47 & 113.04 & 188.40 \\
\hline 豊島区 & 163.43 & 178.66 & 150.72 & 251.20 \\
\hline 第 3プロック & 0.00 & * 491.16 & 558.48 & 930.80 \\
\hline 台東区 & 13.34 & 88.66 & 93.90 & 156.50 \\
\hline 墨田区 & 53.31 & 120.70 & 131.22 & 218.70 \\
\hline 江東区 & 0.00 & * 328.16 & 224.52 & 374.20 \\
\hline 荒川区 & 36.14 & 56.43 & 108.84 & 181.40 \\
\hline 第 4プロック & 337.88 & 672.97 & 581.04 & 968.40 \\
\hline 品川区 & 143.49 & 261.97 & 198.66 & 331.10 \\
\hline 大田区 & 194.39 & 411.00 & 382.38 & 637.30 \\
\hline 第 5 フロック & 710.31 & $1,246.22$ & $1,486.98$ & $2,478.30$ \\
\hline 目黑区 & 107.42 & 143.70 & 145.32 & 242.20 \\
\hline 世田谷区 & 298.79 & 520.85 & 464.34 & 773.90 \\
\hline 中野区 & 180.87 & 210.80 & 186.96 & 311.60 \\
\hline 杉並区 & 192.03 & 275.12 & 312.96 & 521.60 \\
\hline 練馬区 & 0.00 & * 164.55 & 377.40 & 629.00 \\
\hline 第6プロック & 117.86 & 363.27 & 514.98 & 853.30 \\
\hline 北区 & 50.88 & 126.87 & 205.02 & 341.70 \\
\hline 板橋区 & 66.98 & 236.40 & 309.96 & 516.60 \\
\hline 第 7プロック & 0.00 & $* 1,058.76$ & 985.92 & $1,643.20$ \\
\hline 足立区 & 0.00 & * 255.41 & 378.24 & 630.40 \\
\hline 葛飾区 & 45.06 & 179.18 & 255.54 & 425.90 \\
\hline 江戸川区 & 0.00 & * 669.23 & 352.14 & 586.90 \\
\hline 合 区単位 & $1,749.66$ & $5,102.43$ & $4,806.96$ & $8,011.60$ \\
\hline プロック & $1,532.90$ & $4,885.67$ & $4,806.96$ & $8,011.60$ \\
\hline 区部全域 & $1,466.63$ & $4,819.40$ & $4,806.96$ & $8,011.60$ \\
\hline
\end{tabular}

（注）仮設住宅設置必要公園面積の*印は現在の公園面積。
の用地を利用した場合として不足用地面積を求めたが、現実的には、 樹木を除去するとか、二階建ての仮設住宅を建設するとか、あるい は国有地地や民有地を利用すること等が課題となる。

現在、緑化政策は各区それそれに行われているが、当面の目標と して、災害時の仮設住宅の建設という面からも、被害想定に見合っ た仮設住宅数を収容できることを目標に、都市公園の整備を見直し をする必要もあると思われる。

今回の検討は、仮設住宅の最大収容数からみた検討であった。し かし今後は、集会所等の生活関連施設等を含めた検討も課題となる。 また、災害時における土地利用には、コミ処理等の問題もあり、今 後このような問題を含めた検討が課題となる。

〈補注〉

1）応急仮設住宅の検討には、過去の事例を参考に公有地と民有地の割合を定 め検討することも課題であるが、都市によるオープンスペースの量の違いな どの問題もあり、またここでは、理想として公共のオーブンスベースを前提 としているため、民有地を含めた検討については除いた。

2)「東京における地震被害の想定に関する調查研究」（平成 3 年 9 月、東京 都防災会議）この調查研究で、区部・多摩地域については、相模卜ラフに震 源を持つ関東地震（M7.9程度）の再来を基本前提としている。想定地震は、 冬の夕方午後 6 時頃に発生するものとし、その時の風速は $6 \mathrm{~m} /$ 秒程度。

住居制約世帯数は、「手法・提言編」に上る。

3 ) 東京都長期計画: 昭和 57 年 12 月

4 ）公園のデー夕は、平成 6 年 4 月 1 日現在の東京都建設局公園緑地部の公園 調書による。

5 ）住宅地図はゼンリンの住宅地図（1994年版）を使用。 住宅地図は、1/2500の地形図に比へ、通路、便所、啫水、塀その他の工作 物等に関する情報量が多く、作業に当たっては住宅地図を使うこととした。 面積等には多少の誤差はあるものの、住宅地四は航空写真をもとに作成して おり、今回の作業では、大きな誤差につながらないと判断した。

6 ）公園・緑地の樹木被覆率は、各区で実施した緑被率調查の最新の報告書上 り、都市構造区分別の公園・緑地の緑被率のうちの樹木被榎率の值とした。 ただし江戸川区と杉並区は、その值がないため区全体の緑被率を用いた。

また高木の下に纳設住宅を設置することは、落ち葉による屋根材の傷み、 桶のつまりなど管理面での問題があり、ここでは高木の下に仮設住宅を設置 しないこととし、樹木被覆率をそのまま使った。

7 ）厚生省事務次官通達（昭和40年 5 月11日）厚生省社第 162 号、第 1 救助の 程度、方法及び期間、1 . 収容施設の供与、（2）応急仮設住宅の1。東京 都の地域防災計画における仮設住宅の設置戸数はこの通達に準し、原則とし て3割以内としている。

8 ）仮設住宅 1 戸当たりの用地面積については、 $46.2 \mathrm{~m}^{2}$ (横浜市地域防琰計画、 平成元年度修正版）があるが、ここでは最小必要面積として 1 戸当たり $50 \mathrm{~m}^{2}$ と設定した。

9 ）仮設住宅の戸当たり必要公園面積については、平成 7 年 7 月 19 日の都計答 申第25号「今後の都市公園等の整備と管理はいかにあるべきか」の中の、都 市公園等の整備の中長期目標における 21 世紀初頭の目標に、昭和 51 年 6 月 9 日建設事移次官通達の「都市緑化対策推進要綱」都市公園の緑化面稓、及ひ 都市公園法による施設の建筮面積を参考に、公園の緑化部分と施設部分を除 いた割合が仮設住宅の最小必要面積として設定した。

それによると、住区基幹公園と都市基幹公園と大規模公園で、公園面積の $57.5 \%$ を占め、その他の公園は公園面皘の $42.5 \%$ を占める。ここで、住区基 幹公園と都市基幹公園の緑化面積は50\% \%であり、大規模公園の緑化面積を 50 \%、その他の公園の緑化面皘を $75 \%$ と設定すると、公園全体の緑化部分は、 $60.625 \%(0.575 \times 0.5+0.425 \times 0.75)$ となる。それに建べい辛の $2 \%$ を加え ると $62.6 \%$ となる。施設によっては建べい率の上乗せがあることを考感し、 緑化部分と施設部分て $65 \%$ とし、残りを仮設住宅部分と寸る。

この場合仮設住宅の戸当たり公園面積は、 $50\left(\mathrm{~m}^{2}\right) \div 0.35(\%)=142.86\left(\mathrm{~m}^{2}\right)$ となるか、ここでは最小必要公園面積として戸当たり $150 \mathrm{~m}^{2}$ と設定した。

10）都市公園法施行令第一条（平成 5 年 6 月一部改正）に、住民一人当たりの 都市公園の教地面積の標準として規程されている。

11）東京都長期計画では公園の整備目標として、都立公園のほ加区市町村立公 園、国民公園などを含み一人当たり公園面積を 6 四光としている。

12）ここで人口は、住民基本台帳による平成 4 年 3 月末日現在の人口。

\section{〈参考文献〉}

（1）越山健治，室崎益輝：阪神・淡路大震㷋に才ける府急仮設住宅供給に関 寸万研究, 都市計画論文集, N0.31，PP781７86, 1996.11 